\title{
Left Atrium Volume Index and Aortic Stiffness as Predicting Factors for Severity of Coronary Artery Disease
}

\author{
MOHAMED M. EL-ZOGHBY, M.Sc.; MAI M.A. SALAMA, M.D.; SAMIA M. SHARAF AL-DEEN, M.D. and \\ LAMIAA A. KHEDR, M.D.
}

The Department of Cardiovascular Medicine, Faculty of Medicine, Tanta University, Tanta, Egypt

\begin{abstract}
Background: Recently, it has been demonstrated that left atrial distension and aortic stiffness have a predictive value for cardiovascular outcomes especially in high-risk, elderly, and hypertensive adults.

Aim of Study: Evaluation of predictive value of Left Atrium Volume Index (LAVI) and aortic stiffness for severity of angiographic pattern of Coronary Artery Disease (CAD).

Methods: A prospective observational cohort single-center study conducted from May 2016 to May 2017, at Cardiovascular Medicine Department, Tanta University Hospitals in Gharbia Governorate, Egypt. The study enrolled 100 consecutive adult patients of both genders who were diagnosed with chronic stable coronary artery disease and were candidates for invasive coronary angiography. Each patient was subjected to echocardiographic assessment for Left Atrium Volume Index (LAVI) and Aortic Stiffness Index (ASI) followed by invasive coronary angiography for assessment of severity of coronary artery disease by Gensini score. Patients were classified into 3 groups by Gensini score: Group I (gensini score equal zero), Group II (Gensini score more than 0 and less than 20) and Group III (Gensini score equal or more than 20).
\end{abstract}

Results: The prevalence of severe CAD was higher among patients with high LAVI ( $p$-value 0.002) and ASI ( $p$-value $0.05)$. The significant positive relation between LAVI and Gensini score was mainly between Groups II, III (non-severe and severe coronary artery disease). ASI was more sensitive than LAVI for detection of the severity of CAD as ASI showed statistically significant positive strong correlation with the coronary angiographic score $(p=0.001)$ while LAVI showed no significant correlation with the coronary angiographic score $(p=0.061)$. The LAVI carried sensitivity of $67 \%$ and specificity of $49.5 \%$ in predicting CAD with cutoff value $>19.5$. While The ASI carried sensitivity of $66.7 \%$ and specificity of $21 \%$ in predicting CAD with cutoff value $>2.88$.

Conclusion: It was demonstrated that there is significant elevation at aortic stiffness index and left atrium volume index within the group of patient with the higher Gensini score. So ASI and LAVI could be used as promising factors for evaluation of the severity of coronary artery disease.

Correspondence to: Dr. Mohamed M. El-Zoghby, The Department of Cardiovascular Medicine, Faculty of Medicine, Tanta University, Tanta, Egypt
Key Words: Left atrium volume index - Aortic stiffnessinvasive coronary angiography - Gensini score.

\section{Introduction}

HEART disease was found to be a major cause of death worldwide. The high prevalence of risk factors that predispose Coronary Artery Disease (CAD) even after proper management of previous acute coronary syndromes will increase the incidence of the future acute coronary syndrome [1].

Atherosclerosis is a combination of two processes: Atherosis and sclerosis. Sclerosis depends on aortic stiffness that indicates deterioration of aortic elastic properties. It was demonstrated that increased aortic stiffness even in non-diabetic patients, is associated with elevated cardiovascular risk through increased ventricular mass and diminished diastolic coronary perfusion [2]

Aortic stiffness could be assessed by different methods including invasive and non-invasive techniques [3]. Aortic stiffness was found side by side with Central Pulse Pressure (CPP) to be predictors of Coronary Artery Disease (CAD) [4] . It also predisposes to carotid intima-media thickening, atheroma formation, and plaque rupture which may play a major rule in the pathogenesis of acute cardiovascular events [5]. The function and structure of left ventricle are also influenced by aortic stiffening [6].

The diastolic mitral valve opening leads to transmission of the filling pressure of left ventricle to left atrium causing that its size is to be affected by the same factors of diastolic filling pressure. Recently, it has been demonstrated that left atrial distension and aortic stiffness have a predictive value for cardiovascular outcomes especially in high-risk, elderly, and hypertensive adults [7] 
The goal of the present study was to demonstrate the relationship between echocardiographic parameters including left atrium volume index and aortic stiffness and severity of angiographic pattern of coronary artery disease.

\section{Patients and Methods}

The study was conducted as a prospective observational cohort single-center study from May 2016 to May 2017, at Cardiovascular Medicine Department, Tanta University Hospitals in Gharbia Governorate, Egypt.

The study included 472 consecutive adult patients of both genders who were diagnosed with chronic stable coronary artery disease and were candidates for invasive coronary angiography. 372 of them were excluded because they met the exclusion criteria. Finally, 100 patients were enrolled in the study. An informed consent was taken from all participants.

Each patient was subjected to echocardiographic assessment for Left Atrium Volume Index (LAVI) and Aortic Stiffness Index (ASI) followed by invasive coronary angiography for assessment of severity of coronary artery disease by Gensini score. Patients were classified into 3 groups by Gensini score: Group I (Gensini score equal zero), Group II (Gensini score more than 0 and less than 20) and Group III (Gensini score equal or more than 20).

Patients included in this study were adult patients aged over 18 years old who would subjected for invasive coronary angiography for evaluation of the severity of coronary artery disease.

Exclusion criteria were patients with reduced EF $(<50 \%)$, acute coronary syndrome within 2 weeks, decompensate heart failure, atrial fibrillation, congenital heart disease, valvular heart disease, cardiomyopathies, decompensated liver disease, end-stage renal disease and finally patient under 18 years old.

All included patients were subjected to detailed history taking (for age, gender and history of risk factors for CAD), clinical examination, twelvelead electrocardiogram, laboratory investigations, echocardiographic examination (for assessment of diastolic function, left atrium volume and aortic stiffness) and finally invasive coronary angiography (for assessment of CAD).

Echocardiographic examinations were done for every patient with Vivid 7 dimension; (General Electric Medical Systems, Horten, Norway) equipped with a $2.5-\mathrm{MHz}$ variable-frequency transducer. Standard views were performed according to American Society of Echocardiography with ECG tracing and were obtained in 2D and color TDI modes [8,9]

In apical 4-chamber and apical 2-chamber views, the biplane area-length method was used to assess the LA volume that occurs at ventricular end systole measured just before the opening of the mitral valve (end of T wave on ECG) Fig. (1) [10] .

Left atrium volume was indexed to body surface area. BSA was calculated by a simple and commonly used formula (Mosteller formula) [11]

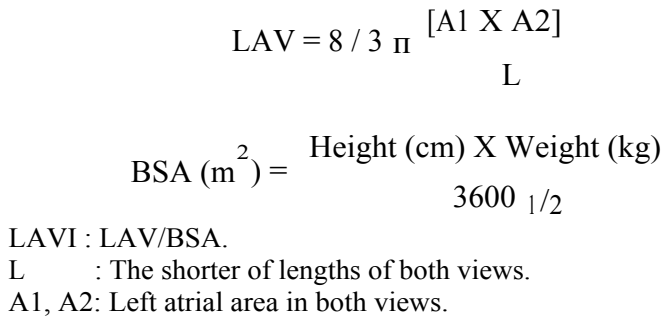

Two-dimensional guided M-mode evaluation of maximal systolic (AoS) and minimal diastolic (AoD) aortic diameters together with blood pressure measured by cuff sphygmomanometer were used for assessment of aortic elasticity. The following indexes of aortic elasticity were calculated Fig. (2):

Aortic strain $(\%)=\frac{100(\mathrm{AoS}-\mathrm{AoD})}{\mathrm{AoD}}$

Aortic stiffness index $($ AoSI $)=\operatorname{Ln}(\mathrm{SBP} / \mathrm{DBP}) /[(\mathrm{AoS}-\mathrm{AoD})$ /AoD]

$\mathrm{Ln}$ (SBP/DBP) refers to the natural logarithm of the relative blood pressure [12]

Blood pressure was measured at the end of echocardiographic evaluation in the supine position. AoD and AoS were evaluated off-line by the principal investigator blinded to the identity of the subject.

Angiographic evaluations were done by two experienced operators, who were blinded to the study. The extent and severity of CAD were assessed by Gensini score. The Gensini score was obtained by assessment of the severity of lesion as it is expressed by specific score (reductions of $25 \%, 50 \%, 75 \%, 90 \%, 99 \%$, and complete occlusion were given Gensini scores of 1, 2, 4, 8, 16, and 32 , respectively) then it was multiplied by the score of functional importance of the affected segment of the vessel [13] 
Statistical presentation and analysis of the present study were conducted, using the mean, Standard Deviation (SD), chi-square test, ANOVA test and ROC analysis by SPSS Version 20.

Subjects were informed about the purpose and procedure of the study and benefits of sharing in it. Ethical considerations of the study were carried out according to that of Declaration of Helsinki.
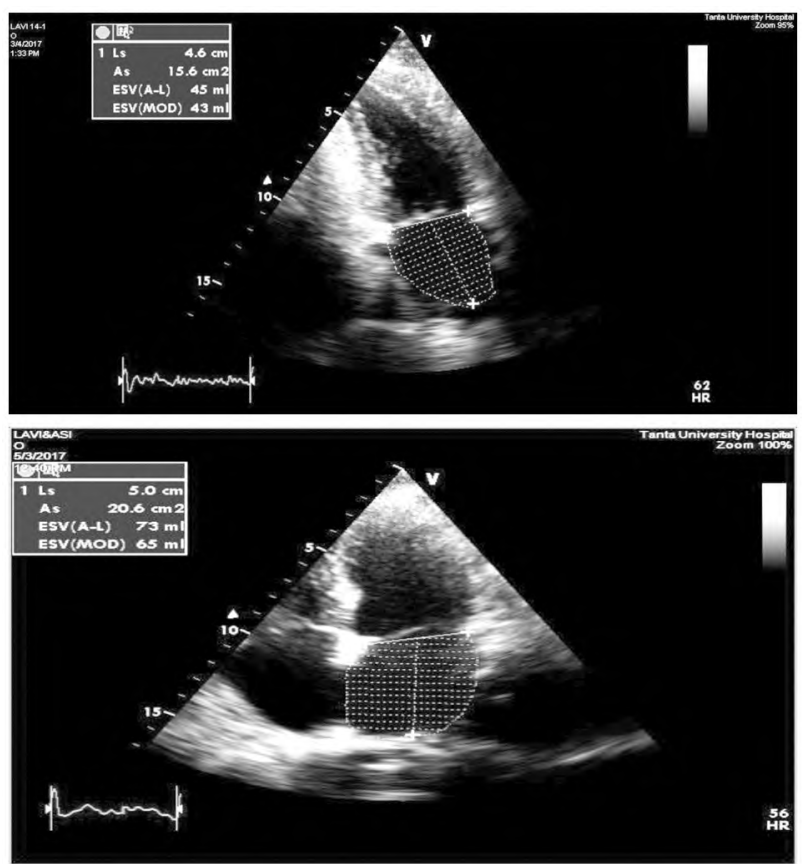

Fig. (1): Left atrium volume assessment by $2 \mathrm{D}$ echocardiography from the present study.

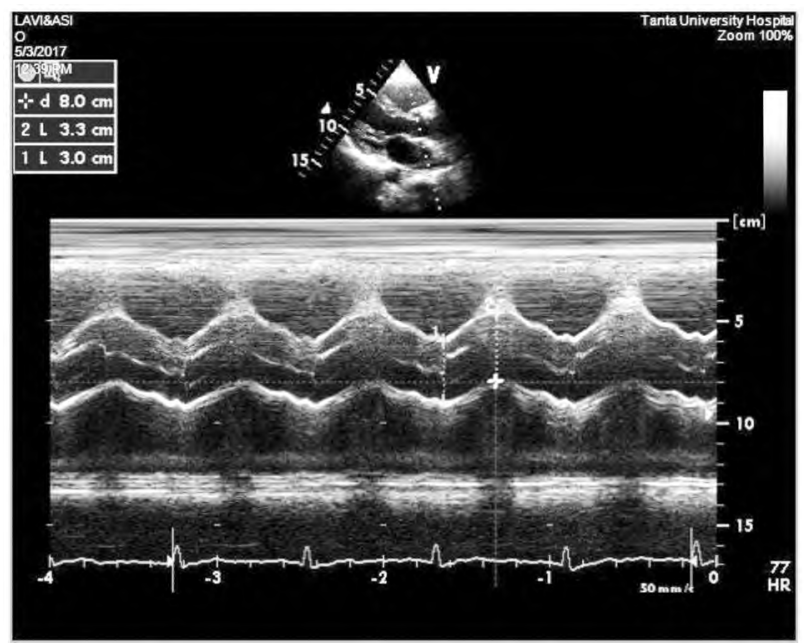

Fig. (2): Measurements of Systolic (S) and Diastolic (D) diameters of the ascending aorta from the present study.

\section{Results}

The sample was divided according to the angiographic severity of coronary artery disease by Gensini score into three groups: Group I (Gensini score equal zero, $n=24)$, Group II (Gensini score more than 0 and less than 20, $\mathrm{n}=21$ ) and Group III (Gensini score equal or more than 20, $\mathrm{n}=55$ ).

One hundred patients, fifty-one men $(51 \%)$ and forty-nine women (49\%) were enrolled in the study. Their age ranged from 31 to 74 years. There was no significant difference between the 3 groups regarding age and sex distribution among the study population.

There was no significant difference between the 3 groups regarding the clinical and laboratory characteristics of the study population except for Triglyceride (TG) $(p=0.004)$ (Tables 1,2).

There was a statistically significant difference between the 3 groups regarding LAVI ( $p=0.002)$ and ASI $(p=0.05)$ among the study population (Table 3). While there was no significant difference between the 3 groups regarding other Echocardiographic characteristics except $\mathrm{E} / \mathrm{A}(p=0.011), \mathrm{E} / \mathrm{è}$ $(p=0.008)$ and IVRT $(p=0.019)$ (Table 6).

The Receiver Operating Characteristics (ROC) analysis was performed to compare the performance and predictive accuracy of LAVI and ASI for predicting severity of CAD. The Areas Under the Curve (AUC) for LAVI and ASI were 0.497, and 0.151 ( $p=0.984, p=0.040$, respectively).

The LAVI carried sensitivity of $67 \%$ and specificity of $49.5 \%$ in predicting CAD with cutoff value $>19.5$. While the ASI carried sensitivity of $66.7 \%$ and specificity of $21 \%$ in predicting CAD with cutoff value $>2.88$. So, these indices do not have a strong predictive value for severity of CAD (Table 4).

The significant relation between ASI, LAVI and prediction of severity of CAD were affected after adjustment for other variables affecting severity of CAD such as; E/è, E and IVRT (Table 5).

There was no significant correlation between Coronary angiographic score and different variables among the study population except for ASI, E, E/A and IVRT which showed statistically significant positive correlations with coronary angiographic score with $p$-value $0.001,0.001,0.001$ and 0.001 respectively and except for è and á which showed statistically significant negative correlations with coronary angiographic score with $p$-value 0.005 and 0.026 respectively (Table 7) Figs. $(3,4)$. 
Table (1): Clinical characteristics of the study patients.

\begin{tabular}{|c|c|c|c|c|c|}
\hline Characteristics & $\begin{array}{l}\text { Group I } \\
(\mathrm{n}=24)\end{array}$ & $\begin{array}{l}\text { Group II } \\
(\mathrm{n}=21)\end{array}$ & $\begin{array}{l}\text { Group III } \\
(\mathrm{n}=55)\end{array}$ & $\begin{array}{l}\text { Sig. } \\
\text { Test }\end{array}$ & $p$ \\
\hline $\begin{array}{r}B M I\left(\mathrm{Kg} / \mathrm{m}^{2}\right): \\
\text { Mean } \pm \mathrm{SD}\end{array}$ & $28.74 \pm 4.5$ & $30.06 \pm 4.26$ & $29.09 \pm 5.27$ & $\begin{array}{l}\mathrm{F} \\
1.558\end{array}$ & 0.216 \\
\hline $\begin{array}{l}B S A\left(m^{2}\right): \\
\quad \text { Mean } \pm \mathrm{SD}\end{array}$ & $1.90 \pm 0.19$ & $1.98 \pm 0.14$ & $1.96 \pm 0.19$ & $\begin{array}{l}\mathrm{F} \\
0.439\end{array}$ & 0.646 \\
\hline $\begin{array}{l}\text { Diabetes mellitus: } \\
\quad \text { Present }\end{array}$ & $6(14.3 \%)$ & $9(21.4 \%)$ & $27(64.3 \%)$ & $\begin{array}{l}\chi^{2} \\
3.989\end{array}$ & 0.136 \\
\hline $\begin{array}{l}\text { Hypertension: } \\
\text { Present }\end{array}$ & $18(32.7 \%)$ & $12(21.8 \%)$ & $25(45.5 \%)$ & $\begin{array}{l}\chi^{2} \\
5.943\end{array}$ & 0.051 \\
\hline $\begin{array}{l}\text { Smoking: } \\
\text { Present }\end{array}$ & $9(23.1 \%)$ & $12(30.8 \%)$ & $18(46.2 \%)$ & $\begin{array}{l}\chi^{2} \\
3.838\end{array}$ & 0.147 \\
\hline
\end{tabular}

Table (2): Laboratory characteristics among the study groups.

\begin{tabular}{|c|c|c|c|c|c|}
\hline Characteristics & $\begin{array}{l}\text { Group I } \\
(\mathrm{n}=24)\end{array}$ & $\begin{array}{l}\text { Group II } \\
(\mathrm{n}=21)\end{array}$ & $\begin{array}{l}\text { Group III } \\
(\mathrm{n}=55)\end{array}$ & F & $p$ \\
\hline $\begin{array}{l}L D L(m g / d l): \\
\quad \text { Mean } \pm \text { SD }\end{array}$ & $129.54 \pm 59.22$ & $122.86 \pm 48.94$ & $141.51 \pm 88.76$ & 0.537 & 0.586 \\
\hline $\begin{array}{r}H D L(m g / d l): \\
\text { Mean } \pm \mathrm{SD}\end{array}$ & $47.92 \pm 19.29$ & $49.29 \pm 6.68$ & $55.57 \pm 19.03$ & 2.067 & 0.132 \\
\hline $\begin{array}{l}\text { Cholesterol }(\mathrm{mg} / \mathrm{dl}) \text { : } \\
\quad \text { Mean } \pm \mathrm{SD}\end{array}$ & $207.17 \pm 51.29$ & $187.67 \pm 62.25$ & $229.93 \pm 83.11$ & 2.789 & 0.066 \\
\hline $\begin{array}{l}T G(m g / d l): \\
\text { Mean } \pm \text { SD }\end{array}$ & $123.92 \pm 41.54$ & $140.67 \pm 56.31$ & $176.18 \pm 78.35$ & 5.807 & $0.004 *$ \\
\hline
\end{tabular}

Table (3): Left Atrium Volume Index (LAVI) and Aortic Stiffness Index (ASI) among study groups.

\begin{tabular}{|c|c|c|c|c|c|}
\hline Characteristics & $\begin{array}{l}\text { Group I } \\
(n=24)\end{array}$ & $\begin{array}{c}\text { Group II } \\
(\mathrm{n}=21)\end{array}$ & $\begin{array}{l}\text { Group III } \\
(n=55)\end{array}$ & $\mathrm{F}$ & $p$ \\
\hline $\begin{array}{c}L A V I\left(\mathrm{ml} / \mathrm{m}^{2}\right): \\
\quad \text { Mean } \pm \mathrm{SD}\end{array}$ & $19.54 \pm 4.42$ & $17.29 \pm 3.84$ & $21.40 \pm 4.54$ & 6.958 & $0.002 *$ \\
\hline Comparison between groups & $p 10.088$ & $p_{2} 0.001 *$ & $p_{3} 0.086$ & & \\
\hline $\begin{array}{l}A S I: \\
\quad \text { Mean } \pm \mathrm{SD}\end{array}$ & $4.33 \pm 1.74$ & $4.71 \pm 1.77$ & $5.64 \pm 2.76$ & 2.948 & $0.05 *$ \\
\hline $\begin{array}{l}* \text { : Statistically significant. } \\
\text { F : One-Way Analysis of Varian } \\
\text { Subgroup analysis was done by } \\
p_{1} \text { : Comparing group } 1 \text { with gro }\end{array}$ & $\begin{array}{l}\text { (ANOVA). } \\
\text { st Hoc LSD. } \\
2 .\end{array}$ & $\begin{array}{ll}p_{2} & : \\
p_{3}: & : \\
\text { LAVI }: \text { I } \\
\text { ASI }:\end{array}$ & \multicolumn{3}{|c|}{$\begin{array}{l}\text { Comparing group } 2 \text { with group } 3 . \\
\text { : Comparing group } 3 \text { with group } 1 . \\
\text { : Left Atrium Volume Index. } \\
\text { : Aortic Stiffness Index. }\end{array}$} \\
\hline
\end{tabular}

Table (4): Agreement (sensitivity, specificity and accuracy) for ASI, and LAVI with coronary angiographic score.

\begin{tabular}{lccccccc}
\hline & Cutoff & AUC & $p$ & Sensitivity & Specificity & PPV & NPV \\
\hline ASI & $>2.88$ & 0.151 & $0.040^{*}$ & 66.7 & 21.0 & 51.9 & 47.6 \\
LAVI & $>19.5$ & 0.497 & 0.984 & 67.0 & 49.5 & 68.6 & 65.3 \\
\hline
\end{tabular}

ASI : Aortic Stiffness Index.

PPV : Positive Predictive Value.

LAVI : Left Atrium Volume Index.

NPV : Negative Predictive Value.

AUC : Area Under the Curve. 
Table (5): Multivariate analysis logistic regression for severity of coronary artery disease by Genisini score.

\begin{tabular}{|c|c|c|c|c|c|c|}
\hline & \multirow{2}{*}{ B } & \multirow{2}{*}{ SE } & \multirow{2}{*}{ Sig. } & \multirow{2}{*}{ OR } & \multicolumn{2}{|c|}{$95 \% \mathrm{CI}$} \\
\hline & & & & & LL & UL \\
\hline ASI & -0.142 & 0.174 & 0.174 & 0.867 & 0.617 & 1.220 \\
\hline LAVI & -0.264 & 0.084 & 0.084 & 0.768 & 0.652 & 0.904 \\
\hline E/è & -0.433 & 0.246 & 0.246 & 0.648 & 0.401 & 1.049 \\
\hline $\mathrm{E}$ & -9.462 & 4.847 & 4.847 & 7.773 & 5.823 & 1.038 \\
\hline IVRT & -0.004 & 0.023 & 0.023 & 0.996 & 0.953 & 1.041 \\
\hline $\begin{array}{l}\mathrm{B}: \text { Un } \\
\mathrm{SE}^{*}: \mathrm{Sta} \\
\quad: \text { Sta }\end{array}$ & $\begin{array}{l}\text { ized } \\
\text { ror. } \\
\text { sign }\end{array}$ & & $\begin{array}{l}\text { OR: Od } \\
\text { CI : Co }\end{array}$ & terval. & $\begin{array}{l}\text { LL } \\
\text { UL }\end{array}$ & $\begin{array}{l}\text { Limit. } \\
\text { Limit. }\end{array}$ \\
\hline
\end{tabular}

Table (6): Echocardiographic characteristics among the study groups.

\begin{tabular}{|c|c|c|c|c|c|c|}
\hline Characteristic & & $\begin{array}{l}\text { Group I } \\
(\mathrm{n}=24)\end{array}$ & $\begin{array}{c}\text { Group II } \\
(\mathrm{n}=21)\end{array}$ & $\begin{array}{c}\text { Group III } \\
(\mathrm{n}=55)\end{array}$ & F & $p$ \\
\hline A.strain (\%): & Mean $\pm \mathrm{SD}$ & $9.25 \pm 3.51$ & $10.87 \pm 5.49$ & $10.59 \pm 5.17$ & 0.788 & 0.458 \\
\hline$E F \%$ : & Mean \pm SD & $65.38 \pm 5.12$ & $64.71 \pm 5.27$ & $63.60 \pm 6.83$ & 0.767 & 0.467 \\
\hline$E D V(m l):$ & Mean $\pm \mathrm{SD}$ & $121.75 \pm 18.70$ & $124.81 \pm 12.42$ & $124.95 \pm 31.99$ & 0.133 & 0.876 \\
\hline $\operatorname{LVMI}\left(\mathrm{g} / \mathrm{m}^{2}\right)$ : & Mean \pm SD & $99.50 \pm 22.11$ & $99.05 \pm 16.86$ & $97.07 \pm 24.03$ & 0.125 & 0.883 \\
\hline$E(\mathrm{~m} / \mathrm{s}):$ & Mean \pm SD & $0.69 \pm 0.09$ & $0.65 \pm 0.07$ & $0.71 \pm 0.13$ & 2.377 & 0.098 \\
\hline$A(\mathrm{~m} / \mathrm{s}):$ & Mean \pm SD & $0.75 \pm 0.12$ & $0.85 \pm 0.07$ & $0.78 \pm 0.23$ & 1.691 & 0.190 \\
\hline$\grave{e}(\mathrm{~m} / \mathrm{s}):$ & Mean \pm SD & $0.11 \pm 0.02$ & $0.11 \pm 0.02$ & $0.10 \pm 0.04$ & 1.820 & \\
\hline$\dot{a}(\mathrm{~m} / \mathrm{s}):$ & Mean \pm SD & $0.12 \pm 0.03$ & $0.11 \pm 0.04$ & $0.11 \pm 0.03$ & 0.959 & \\
\hline$E / A$ : & Mean \pm SD & $0.96 \pm 0.23$ & $0.76 \pm 0.08$ & $1.00 \pm 0.38$ & 4.696 & * \\
\hline E/è: & Mean \pm SD & $6.68 \pm 1.62$ & $5.91 \pm 1.12$ & $7.72 \pm 2.82$ & 5.147 & $0.019 *$ \\
\hline $\operatorname{IVRT}(\mathrm{ms})$ : & Mean \pm SD & $78.83 \pm 8.57$ & $84.71 \pm 19.27$ & $90.55 \pm 18.57$ & 4.157 & \\
\hline $\begin{array}{l}\mathrm{F} \quad \text { : One- } \\
\text { A.strain: Aorti } \\
\mathrm{EF} \quad \text { : Eject }\end{array}$ & $\begin{array}{l}\text { way Analysis } \\
\text { c strain. } \\
\text { ion fraction. }\end{array}$ & 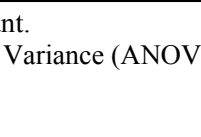 & $\begin{array}{l}\text { LVMI } \\
\text { IVRT }\end{array}$ & $\begin{array}{l}\text { Left Ventricle M } \\
\text { Isovolumic Vent } \\
\text { Time. }\end{array}$ & $\begin{array}{l}\text { Inde } \\
\text { dlar F }\end{array}$ & tion \\
\hline
\end{tabular}

Table (7): Correlation between coronary angiographic score and different variables.

\begin{tabular}{lrc}
\hline & $r$. & $p$ \\
\cline { 2 - 3 } & \multicolumn{2}{c}{ Coronary angiographic score } \\
\hline A.strain (\%) & -0.071 & 0.482 \\
ASI & 0.621 & $0.001^{*}$ \\
LAVI $\left(\mathrm{ml} / \mathrm{m}^{2}\right)$ & 0.188 & 0.061 \\
EF\% & -0.134 & 0.184 \\
LVMI $\left(\mathrm{g} / \mathrm{m}^{2}\right)$ & -0.047 & 0.641 \\
E $(\mathrm{m} / \mathrm{s})$ & 0.419 & $0.001^{*}$ \\
A $(\mathrm{m} / \mathrm{s})$ & -0.146 & 0.148 \\
è $(\mathrm{m} / \mathrm{s})$ & -0.289 & $0.005^{*}$ \\
á $(\mathrm{m} / \mathrm{s})$ & -0.222 & $0.026^{*}$ \\
E/A & 0.413 & $0.001^{*}$ \\
E/è & -0.014 & 0.887 \\
IVRT (ms) & 0.441 & $0.0011^{*}$ \\
EDV (ml) & -0.014 & 0.887 \\
\hline B : Un standardized coefficients. & CI : Confidence Interval. \\
SE : Standard Error. & \multicolumn{2}{c}{ LL : Lower Limit. } \\
OR : Odds Ratio. & UL : Upper Limit. \\
$*$ & Statistically significant at $p \leq 0.05$. &
\end{tabular}

Correlation between coronary angiographic score and ASI

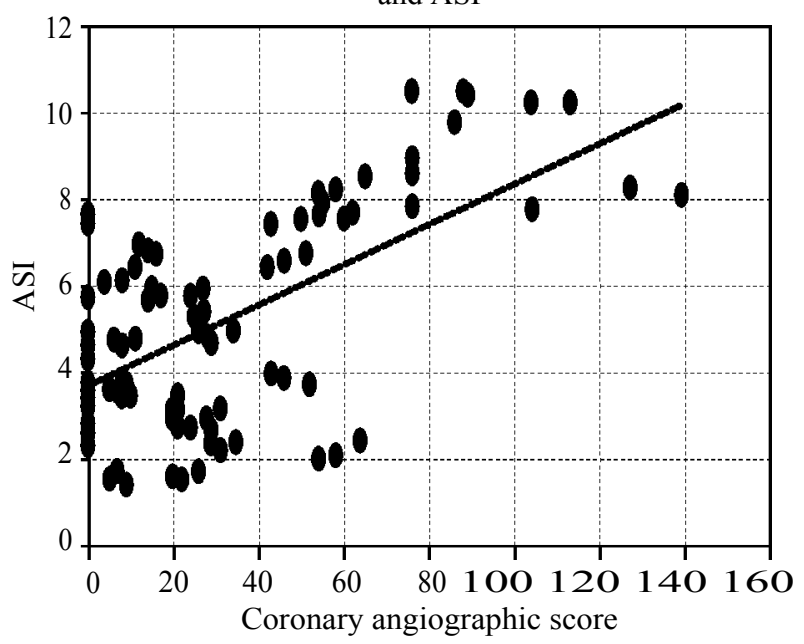

Fig. (3): Correlation between coronary angiographic score and ASI. 


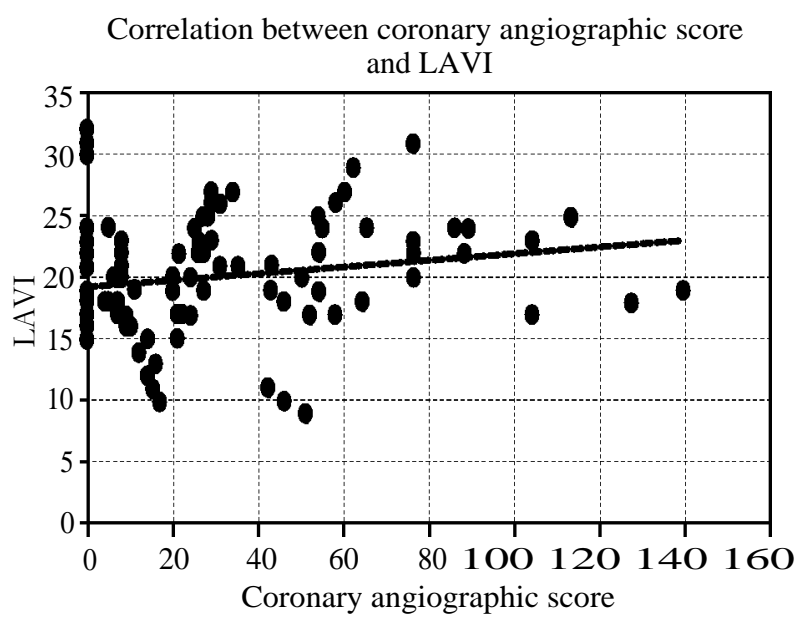

Fig. (4): Correlation between coronary angiographic score and LAVI.

\section{Discussion}

Heart disease was found to be a major cause of death worldwide. The high prevalence of risk factors that predispose to CAD even after proper management of previous acute coronary syndromes will increase the incidence of the future acute coronary syndrome [1].

Atherosclerosis is a combination of two processes: Atherosis and sclerosis. Sclerosis depends on aortic stiffness that indicates deterioration of aortic elastic properties. It was demonstrated that increased aortic stiffness even in non-diabetic patients, is associated with elevated cardiovascular risk through increased ventricular mass and diminished diastolic coronary perfusion [2]

The diastolic mitral valve opening leads to transmission of the filling pressure of left ventricle to left atrium causing that its size is affected by the same factors of diastolic filling pressure. Recently, it has been demonstrated that left atrial distension and aortic stiffness have a predictive value for cardiovascular outcomes especially in high-risk, elderly, and hypertensive adults [7].

The goal of the present study was to demonstrate the relationship between echocardiographic parameters including left atrium volume index and aortic stiffness and severity of angiographic pattern of coronary artery disease.

The most important finding of the present study was that there was a significant correlation between aortic stiffness index and Gensini score. In this study, ASI showed statistically significant positive strong correlation with the coronary angiographic score $(p=0.001)$. ASI showed a significant difference between study groups $(p=0.05)$. ASI carried sensitivity of $66.7 \%$ and specificity of $21 \%$ in predicting CAD with cutoff value $>2.88$. So, this index does not have a strong predictive value for severity of CAD. This might be due to other study limitations that are needed to be controlled in further studies.

It was noticed that there was lack of studies that used ASI and Gensini score as determinants of severity of aortic stiffness and coronary artery disease respectively for assessment of the relation between aortic stiffness and coronary artery disease. Yet, van Popele et al., measured aortic stiffness by pulse wave velocity from the carotid to the femoral artery whereas coronary atherosclerosis was assessed by total calcium score with the results showed that aortic stiffness was associated with atherosclerosis of the coronary arteries in elderly subjects in agreement with the current study [14]

In addition, YT. Kao et al., reported that after dividing the study population into 2 groups by age over and under 50 years of age, the ASI positively correlated with the presentation of at least one $>50 \%$ coronary stenotic plaque in patients aged $>50$ years, as assessed by a 64 -slice cardiac computed tomography angiography [15]

So it could be suggested that aortic stiffness index can be considered as one of the promising parameters for diagnosis of presence or severity of coronary artery disease.

As regard LAVI, the present study found that there was a significant difference between groups of different severity of coronary artery disease ( $p=$ 0.002 ). Subgroup analysis revealed that there was significant positive relation which was mainly between Groups II, III (non-severe and severe coronary artery disease). It was also noticed that mean LAVI of Group I was of higher value than mean LAVI of Group II. Also, LAVI carried sensitivity of $67 \%$ and specificity of $49.5 \%$ in predicting CAD with cutoff value $>19.5$. It may be due to the unreliable size of the population of both groups in relation to Group III and higher prevalence of hypertension among the Group I than Group II. So, this index does not have a strong predictive value severity of CAD.

This came in concordance with the study conducted by N. Roy et al., where LAVI was found to correlate positively with Gensini Score $(p<0.001)$ in 500 subject population of acute myocardial infarction [16]. This came also in agreement with the study conducted by A. Bacaksiz et al., who reported that LAVI was increased in patients with acute myocardial infarction in relation to Gensini 
score $(p<0.01)$ in a study of 160 subject population [17].

So, it could be suggested that LAVI provides a promising parameter for diagnosis of presence or severity of CAD, but this conclusion needs to be re-evaluated with more studies with fewer limitations.

As regards the significant difference of TG between study groups, S. Phababpha et al., reported that a significant elevation of serum TG and reduction in serum HDL levels was found in severe CAD group in comparison with other two groups [18] J. Tarchalski et al., showed that Gensini score was positively correlated with total cholesterol, LDL cholesterol, and TG. There was a negative correlation between Gensini score and HDL cholesterol. The disagreement with the present study may be due to the small sample size of the present study and the results need to be re-evaluated with larger sample size [19]. So the rule of lipid profile as a predictive factor for CAD may need further assessment.

As regards other echocardiographic parameters, the present study showed that the most valuable parameters with statistically significant difference between study groups were E/A, E/è, and IVRT.

A. Bacaksiz et al., reported that IVRT had no significant correlation with Gensini score in patients with acute myocardial infarction in a study of 160 subject population, and E/è was significantly correlated with severity of CAD with $p=0.04$. While L. Mal et al., found the significant correlations between E/è, è with CAD severity $(p=0.031$ and $p=0.033$ respectively) $[\mathbf{1 7 , 2 0 ]}$.

The disagreement between the present study and other studies as regards the echocardiographic parameters may be due to the small sample size of the present study and different inclusion and exclusion criteria between studies. So, it could be suggested that IVRT, E/A, and E/è may be considered of diagnostic parameters for the presence or severity of CAD. Other echocardiographic parameters need to be evaluated to be considered as predicting parameters.

\section{Conclusion:}

It was demonstrated that there is a significant elevation of aortic stiffness index and left atrium volume index within the group of patient with the higher Gensini score. Therefore, ASI and LAVI could be used as promising factors for the evaluation of the severity of coronary artery disease.

\section{Competing interests:}

The authors declare that they have no competing interests.

\section{References}

1- THOM T., HAASE N., ROSAMOND W., HOWARD V.J., RUMSFELD J., MANOLIO T., ZHENG Z.J., FLEGAL K., O'DONNELL C., KITTNER S., LLOYD-JONES D., GOFF D.C., HONG Y., ADAMS R., FRIDAY G., FURIE K., GORELICK P., KISSELA B., MARLER J., MEIGS J., ROGER V., SIDNEY S., SORLIE P., STEINBERGER J., WASSERTHIEL-SMOLLER S., WILSON M. and WOLF P.: American Heart Association Statistics Committee and Stroke Statistics Subcommittee. Heart disease and stroke statistics--2006 update: A report from the American Heart Association Statistics Committee and Stroke Statistics Subcommittee. Circulation; 113: e85151, 2006

2- WESTERHOF N. and O'ROURKE M.F.: Haemodynamic basis for the development of left ventricular failure in systolic hypertension and for its logical therapy. J. Hypertens; 13: 943-52, 1995

3- WOODMAN R.J., KINGWELL B.A., BEILIN L.J., HAMILTON S.E., DART A.M. and WATTS G.F.: Assessment of central and peripheral arterial stiffness: Studies indicating the need to use a combination of techniques. Am. J. Hypertens; 18: 249-60, 2005.

4- PHILIPPE F., CHEMALY E., BLACHER J., MOURAD J.J., DIBIE A., LARRAZET F., LABORDE F. and SAFAR M.E.: Aortic pulse pressure and extent of coronary artery disease in percutaneous transluminal coronary angioplasty candidates. Am. J. Hypertens; 15: 672-7, 2002.

5- TOMONORI T., KEIKO S., SHINKICHI H., YOJI N. and AKIRA T.: Carotid atherosclerosis and arterial peripheral pulse wave velocity in cerebral thrombosis. J. Clin. Neurosci.; 13: 45-9, 2006.

6- LARTAUD-IDJOUADIENE I., LOMPRÉ A.M., KIEFFER P., COLAS T. and ATKINSON J.: Cardiac consequences of prolonged exposure to an isolated increase in aortic stiffness. Hypertension; 34: 63-9, 1999.

7- LANTELME P., LAURENT S., BESNARD C., BRICCA G., VINCENT M., LEGEDZ L. and MILON H.: Arterial stiffness is associated with left atrial size in hypertensive patients. Arch. Cardiovasc. Dis.; 101: 35-40, 2008.

8- LANG R.M., BADANO L.P., MOR-AVI V., AFILALO J., ARMSTRONG A., ERNANDE L., FLACHSKAMPF F.A., FOSTER E., GOLDSTEIN S.A., KUZNETSOVA T., LANCELLOTTI P., MURARU D., PICARD M.H., RIETZSCHEL E.R., RUDSKI L., SPENCER K.T., TSANG W. and VOIGT J.U.: Recommendations for cardiac chamber quantification by echocardiography in adults: An update from the American society of echocardiography and the European association of cardiovascular imaging. Eur. Heart J. Cardiovasc. Imaging; 16: 233-71, 2015.

9- DOUGLAS P.S., KHANDHERIA B., STAINBACK R.F., WEISSMAN N.J., BRINDIS R.G., PATEL M.R., KHANDHERIA B., ALPERT J.S., FITZGERALD D., HEIDENREICH P., MARTIN E.T., MESSER J.V., MILLER A.B., PICARD M.H., RAGGI P., REED K.D., RUMSFELD J.S., STEIMLE A.E., TONKOVIC R., VIJAYARAGHAVAN K., WEISSMAN N.J., YEON S.B., BRINDIS 
R.G., DOUGLAS P.S., HENDEL R.C., PATEL M.R., PETERSON E., WOLK M.J. and ALLEN J.M.: American College of Cardiology Foundation Quality Strategic Directions Committee Appropriateness Criteria Working Group, American Society of Echocardiography, American College of Emergency Physicians, American Society of Nuclear Cardiology, Society for Cardiovascular Angiography and Interventions, Society of Cardiovascular Computed Tomography, Society for Cardiovascular Magnetic Resonance, American College of Chest Physicians, Society of Critical Care Medicine. ACCF/ASE/ACEP/ASNC/ SCAI/SCCT/SCMR 2007 Appropriateness Criteria for Transthoracic and Transesophageal Echocardiography Developed in accordance with the principles and methodology outlined by ACCF: Patel M.R., Spertus J.A., Brindis R.G., Hendel R.C., Douglas P.S., Peterson E., Wolk M.J., Allen J.M., Raskin I.E. ACCF proposed method for evaluating the appropriateness of cardiovascular imaging. J. Am. Coll. Cardiol.; 46: 1606-13 (1). J. Am. Coll. Cardiol., 2007; 50: 187-204, 2005.

10- UJINO K., BARNES M.E., CHA S.S., LANGINS A.P., BAILEY K.R., SEWARD J.B. and TSANG T.S.M.: TwoDimensional Echocardiographic Methods for Assessment of Left Atrial Volume. Am. J. Cardiol.; 98: 1185-8, 2006.

11- MOSTELLER R.D.: Simplified Calculation of BodySurface Area. N. Engl. J. Med.; 317: 1098-1098, 1987.

12- STEFANADIS C., STRATOS C., BOUDOULAS H., KOUROUKLIS C. and TOUTOUZAS P.: Distensibility of the ascending aorta: Comparison of invasive and noninvasive techniques in healthy men and in men with coronary artery disease. Eur. Heart J.; 11: 990-6, 1990.

13- GENSINI G.G.: A more meaningful scoring system for determining the severity of coronary heart disease. Am. J. Cardiol.; 51: 606, 1983.

14- VAN POPELE N.M., MATTACE-RASO F.U., VLIEGENTHART R., GROBBEE D.E., ASMAR R., VAN
DER KUIP D.A., HOFMAN A., De FEIJTER P.J., OUDKERK M. and WITTEMAN J.C.: Aortic stiffness is associated with atherosclerosis of the coronary arteries in older adults: The Rotterdam Study. J. Hypertens; 24: 2371-6, 2006.

15- KAO Y.T., WANG S.T., SHIH C.M., LIN F.Y., TSAO N.W., CHIANG K.H., CHAN C.S., LIN Y.C., HUNG M.Y., HSIEH M.H., SHYU K.G., CHEN J.W., CHANG N.C., YEH J.S. and HUANG C.Y.: Arterial Stiffness Index and Coronary Artery Plaques in Patients with Subclinical Coronary Atherosclerosis. Acta. Cardiol. Sin.; 31: 59-65, 2015.

16- ROY N., MANDAL P.C. and ISLAM S.S.: A study on left atrial volume and its correlation with clinicoangiographic profile in patients with acute myocardial infarction. J. Am. Coll. Cardiol.; 67: S60-S61, 2016.

17- BACAKSIZ A., VATANKULU M.A., KAYRAK M., TELLI H.H., AYHAN S.S., SONMEZ O., ALP A. and BUYUKBAS S.: Assessment of the left atrial volume index and plasma NT-proANP level in patients with acute ST-elevation myocardial infarction. Clinics (Sao Paulo); 68: 997-1003, 2013.

18- PHABABPHA S., KUKONGVIRIYAPAN U., TATSANAVIVAT P., KUKONGVIRIYAPAN V. and PAKDEECHOTE P.: Oxidative Stress and HDL Cholesterol Levels are Independent Predictors of the Severity of Coronary Artery Stenosis in Thai Patients with Coronary Heart Disease Results \& Discussion. Srinagarind. Med. J.; 25: 235-9, 2010.

19- TARCHALSKI J., GUZIK P. and WYSOCKI H.: Correlation between the extent of coronary atherosclerosis and lipid profile. Mol. Cell. Biochem.; 246: 25-30, 2003.

20- MA L., LI Y., WU Z. and MU Y.: A New Potential Predictor of Coronary Artery Disease: The Ratio of Mitral Peak Filling Velocity to Mitral Annular Velocity in Early Diastole. Med. Sci. Monit.; 23: 1180-9, 2017.

\section{مؤشرحجم الآذين الآيسروتصلب الشريان الآبهر كعوامل تنبؤ

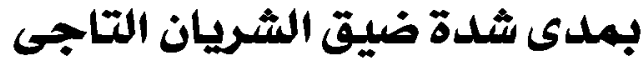

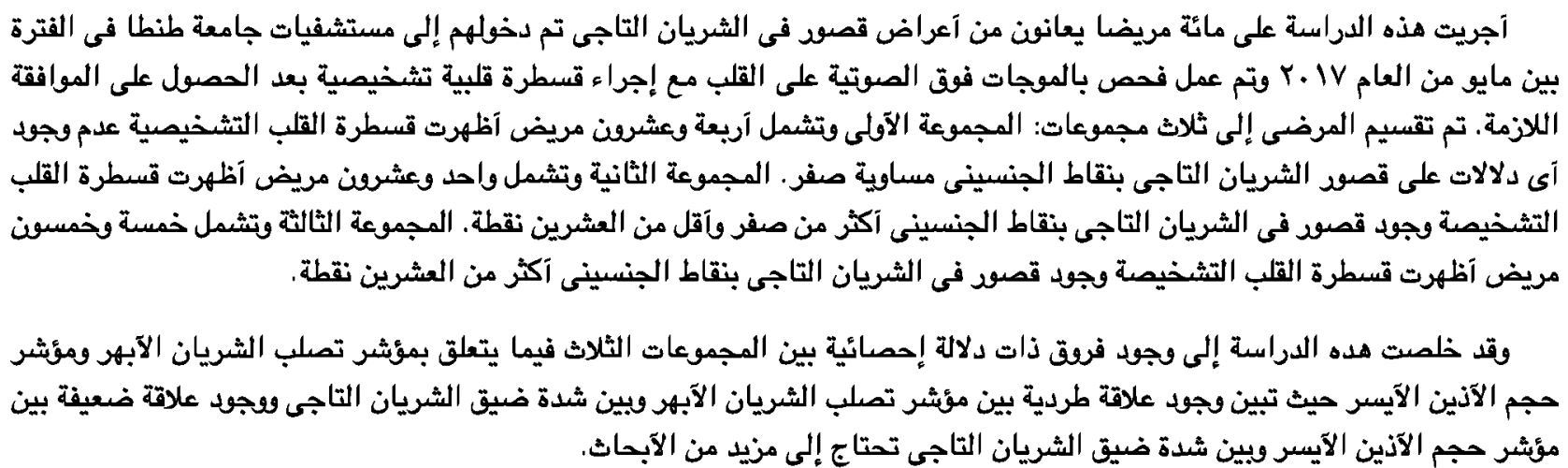

